\title{
Use of an improved $E$. coli method for the measurement of cobalamin in serum: comparison with the $E$. gracilis assay results
}

\author{
NEFERTITI A SOURIAL \\ From the Department of Haematology, St Bartholomew's Hospital, London EC1A 7BE, UK
}

SUMMARY Owing to the higher serum cobalamin results that are obtained by R-binder radioisotopic dilution assay compared to microbiological assays (E. gracilis and L. leichmannii) it was suggested that serum contained a cobamide(s) that could not be detected by the more specific microbiological assays and that a much less specific test organism, which responds to most naturally occurring cobamides, such as the cobamide-dependent $E$. coli mutant, might respond to these cobamide(s) in serum. In an attempt to investigate this possibility an improved and simplified $E$. coli assay for the measurement of cobamide in serum was developed.

The method is described, and the results obtained in normal subjects, in patients with megaloblastic anaemia, and in anaemic pregnant women not suffering from megaloblastic anaemia are reported and compared with $E$. gracilis assay results.

The radioisotopic dilution (RID) assay for serum cobalamin gives consistently higher results than microbiological assays $;^{12}$ the reason for this difference in results is uncertain. However, it was suspected that certain cobamides in serum were reacting with the RID assay but were incapable of promoting the growth of the more specific test organisms Euglena gracilis and Lactobacillus leichmannii used to measure cobalamin in serum. It was therefore possible that the least fastidious and discriminating cobamide-dependent Escherichia coli mutant, ${ }^{3}$ which was isolated by Davis and Mingioli, ${ }^{4}$ might respond to such cobamides. A sensitive and accurate $E$. coli method for the assay was essential if valid inferences were to be drawn from a study based on comparison of microbiological responses.

The requirements of a satisfactory method of assay are: (1) an extraction process by which virtually all the cobalamin is extiacted from serum: (2) a complete medium in which the rate of growth of the test organism would be maximal and the sole limiting factor would be cobalamin; and (3) an actively growing inoculum. None of the existing methods of $E$. coli assay was found to comply with these requirements. A thorough study of the factors affecting the $E$. coli assay was therefore carried out, and an improved, accurate, and simplified method was developed which is described in this paper.

The results obtained with this method are also presented, in comparison with those obtained with the $E$. gracilis assay, in normal subjects, in patients suffering from megaloblastic anaemia, and in anaemic pregnant women.

\section{Material and methods}

EUGLENA GRACILIS ASSAY

The method of Hutner et al. . $^{5}$ using E. gracilis $\mathrm{z}$ strain, modified by Anderson, ${ }^{6}$ was used.

ESCHERICHIA COLI ASSAY

Maintenance of stock culture

E. coli (NCIB 9270) was maintained in a freeze-dried state on strips of filter paper in glass ampoules sealed under vacuum. ${ }^{7}$ The freeze-dried cultures were stored at $8^{\circ} \mathrm{C}$ but could be kept at room temperature. A liquid culture was prepared every two weeks by culturing the contents of the ampoule in $10 \mathrm{ml}$ maintenance medium (Difco Nutrient Broth) and was incubated for $\mathbf{4 0}$ hours.

\section{Preparation of inoculum}

Two to three drops of the 40-hour culture were subcultured in $10 \mathrm{ml}$ fresh nutrient broth and grown for 18 to 20 hours. This was spun down and 
the supernatant was discarded; the cells were washed in $10 \mathrm{ml}$ single-strength medium and finally resuspended in $15 \mathrm{ml}$ single-strength medium. This was carried out under strict aseptic conditions.

\section{Assay medium}

Double-strength medium was made up (Table 1), refrigerated at $8^{\circ} \mathrm{C}$, and stored for up to three weeks.

Table 1 Modified assay medium

\begin{tabular}{lc}
\hline Ingredient & $\begin{array}{c}\text { Concentration } \\
(\text { mmol } / l)\end{array}$ \\
\hline Dipotassium hydrogen phosphate & $80 \cdot 38$ \\
Potassium dihydrogen phosphate & $44 \cdot 09$ \\
Magnesium sulphate hydrate & $0 \cdot 81$ \\
Ammonium sulphate & $15 \cdot 14$ \\
Sodium acetate hydrate & $73 \cdot 49$ \\
Glucose & $138 \cdot 77$ \\
Glycine & $2 \cdot 66$ \\
L-Asparagine & $53 \cdot 29$ \\
L-Arginine & $1 \cdot 15$ \\
L-Glutamic acid & $1 \cdot 36$ \\
L-Histidine & 1.04 \\
L-Tryptophane & 0.98 \\
L-Proline & $1 \cdot 74$ \\
Nicotinic acid & $3 \cdot 25 \dagger$ \\
Para-amino benzoic acid & 1.46 \\
*L-cystine & $83 \cdot 23 \dagger$ \\
\hline
\end{tabular}

*When added.

$\dagger \mu \mathrm{mol} / \mathrm{l}$.

\section{Standard cyanocobalamin solution}

A stock solution of $200 \mu \mathrm{g} / \mathrm{l}(200 \mathrm{ng} / \mathrm{ml})$ was prepared from cyanocobalamin solution containing $250 \mathrm{mg} / \mathrm{l}$ $(250 \mu \mathrm{g} / \mathrm{ml})$ (Cytamen, Glaxo). The stock standard was kept at $8^{\circ} \mathrm{C}$ for up to six weeks. Seven working standard solutions, $5,10,20,40,60,80$, and $100 \mathrm{ng} / \mathrm{l}$, were prepared freshly for each assay by diluting the stock standard solution $(200 \mu \mathrm{g} / \mathrm{l})$ in glass distilled water.

\section{Sodium acetate-acetic acid extraction buffer (pH 4.9, 0.02 м)}

A solution of $0.2 \mathrm{M} \mathrm{Na-acetate}$ was titrated with $0.2 \mathrm{M}$ acetic acid to give a pH of 4.9. The volume was then made up with glass distilled water to give a molarity of $0.02 \mathrm{M}$. Sodium cyanide was added at a concentration of $0.11 \mathrm{mmol} / 1(5.5 \mathrm{mg} / \mathrm{l})$ in buffer corresponding to a concentration of $1.02 \mathrm{mmol} / \mathrm{l}$ $(50 \mathrm{mg} / \mathrm{l})$ of serum. The $0.02 \mathrm{M}$ buffer (containing cyanide) was prepared freshly before each assay.

\section{Collection of serum samples}

Venous blood was collected into sterile containers, using disposable syringes, and allowed to clot at room temperature for approximately 2 hours. Serum was then separated and stored at $-20^{\circ} \mathrm{C}$ until the time of assay.
Preparation of serum for assay

Serum was diluted 1 in 10 in $0.02 \mathrm{M}$ cyanide acetate buffer. The serum-buffer solution was autoclaved at $10 \mathrm{lb}$ pressure for 20 minutes, the proteins were coagulated, and the tubes were cooled, thoroughly mixed, and finally centrifuged. The clear supernatant was then assayed. Usually $1 \mathrm{ml}$ of the deproteinised serum extract was assayed, which, when set up as described below, gave a final dilution of serum of 1 in 40 . However, when a serum cobalamin level was expected to be abnormally low or high, the volumes assayed were $2.0 \mathrm{ml}$ or $0.5 \mathrm{ml}$, corresponding to a final dilution of 1 in 20 or 1 in 80 , respectively.

\section{Assay procedure}

For simplicity, speed, and convenience solutions and sera were added using an automatic variable dilutor (VDO/C/10 Hook and Tucker Instruments Limited).

In this study either $1 \mathrm{ml}$ or $2 \mathrm{ml}$ of serum extract was assayed in duplicate and either $3 \mathrm{ml}$ of $3 / 2$ strength medium or $2 \mathrm{ml}$ of double-strength medium was added respectively. As in the preparation of the serum samples, $1 \mathrm{ml}$ of each of the working standard solutions was diluted with $3 \mathrm{ml}$ of $3 / 2$ strength medium. Alternatively, if the serum was assayed at a 1 in $\mathbf{2 0}$ dilution, the concentration of these working standards was halved, and $2 \mathrm{ml}$ of each standard was diluted with $2 \mathrm{ml}$ of double-strength medium. In either case, tubes containing the standards were set up in duplicate, and three tubes were prepared with no cyanocobalamin solution, two of which were inoculated (control tubes), but one was left uninoculated as a blank. The standards henceforth were treated exactly as the serum samples, and all the tubes were subsequently sterilised by autoclaving at 10 psi for 6 minutes; they were cooled and $0.1 \mathrm{ml}$ of sterile glucose solution $2.8 \mathrm{M}(500 \mathrm{~g} / \mathrm{l})$ was added aseptically using a Smi Micro-re/pettor. Finally, one drop of the washed inoculum was delivered to each tube by means of a sterile Pasteur pipette. Originally one tube from each sample was kept uninoculated as a blank, but later a serum blank was set up only if the serum extract was turbid. The tubes were incubated at $37^{\circ} \mathrm{C}$ for $20-21$ hours.

Each serum sample was assayed in duplicate in at least two different assay batches.

\section{Reading and calculation of results}

The growth of $E$. coli test organism was assessed by measuring the turbidity caused by the bacterial cells. At the end of the incubation period the tubes were cooled in a cold room $\left(8^{\circ} \mathrm{C}\right)$ and thoroughly shaken by a Rotamixer (Hook and Tucker Limited) and then allowed to stand for a few minutes after mixing to allow the air bubbles to rise. 
The optical density or absorbance was measured in a Unicam colorimeter SP1300 using an Ilford 622 blue spectrum $(\lambda=375-535 \mathrm{~m} \mu)$.

The standards were read against the uninoculated blank, and serum samples were read either against the same aqueous blank or against its own blank.

To determine the cobalamin activity of the serum samples, a standard curve was constructed on linear graph paper, the absorbance of the cyanocobalamin standards being plotted against the cyanocobalamin concentration (ng/l).

\section{Subjects studied}

One hundred and twenty-two subjects were studied. These included 47 normal subjects, 62 patients with megaloblastic anaemia, and 13 anaemic pregnant women (Table 2). The diagnosis of megaloblastic anaemia was made on the appearance of bone marrow. Mean cell volume was raised in all these patients except in those in whom megaloblastic anaemia was associated with iron deficiency anaemia.

Before attempting to compare the $E$. coli and $E$. gracilis assay results, it was first necessary to establish that the $E$. coli assay can measure accurately the low concentrations of cobalamin in serum and can differentiate between patients with cobalamin deficiency (pernicious anaemia) and normal control subjects.

Table 2 Diagnostic classification of the 122 subjects studied

\begin{tabular}{ll}
\hline Conditions & No. studied \\
\hline Normal subjects & 47 \\
Megaloblastic anaemia & \\
(a) Cobalamin-deficient patients & 20 \\
Addisonian pernicious anaemia & 1 \\
Chronic atrophic gastritis & 7 \\
Anatomical lesions of the small intestine & 1 \\
Total gastrectomy & 8 \\
Partial gastrectomy & 3 \\
Nropical sprue & 2 \\
(b) Folate-deficient patients & 5 \\
Coeliac disease & 2 \\
Megaloblastic anaemia due to pregnancy & 2 \\
$\quad$ Megaloblastic anaemia due to anticonvulsant & 2 \\
$\quad$ Nutritional megaloblastic anaemia & 3 \\
Alcoholics & 13 \\
\hline
\end{tabular}

\section{Results}

\section{ESCHERICHIA COLI ASSAY}

\section{Normal subjects}

The serum cobalamin concentrations in 47 normal subjects ranged from 190 to $930 \mathrm{ng} / \mathrm{l}$. The distribution of the results (Fig. 1) was skewed and therefore the mean \pm SD was calculated after log transformation. The calculated normal range was 175 to 708 $\mathrm{ng} / \mathrm{l}$ with $95 \%$ confidence limits (mean $\pm 2 \mathrm{SD}$ ), with a geometric mean of $330 \mathrm{ng} / \mathrm{l}$ (Fig. 1).

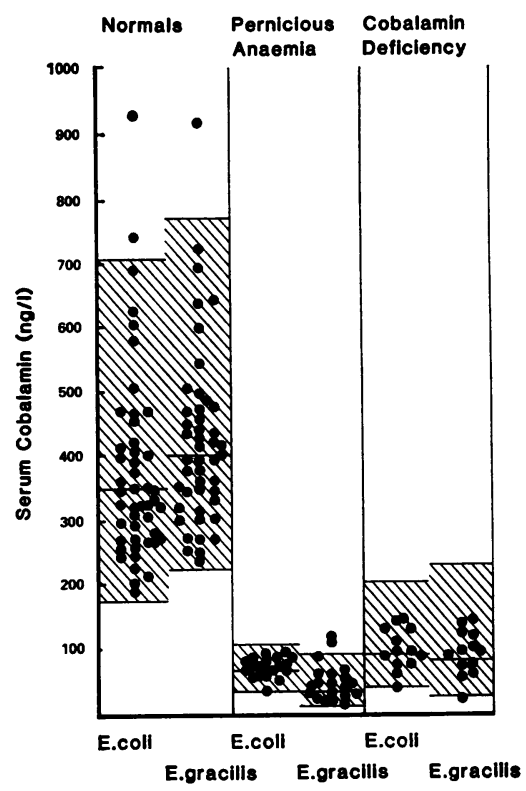

Fig. 1 Serum cobalamin concentrations in normal subjects and in patients with PA and other causes of cobalamin deficiency. Solid line represents geometric mean and the shaded area represents the calculated range (mean $\pm 2 S D$ ).

\section{Pernicious anaemia $(P A)$}

The haemoglobin concentration ranged from 5.7 to $14.4 \mathrm{~g} / \mathrm{dl}$ in the 20 patients with PA, with a mean of $8.5 \mathrm{~g} / \mathrm{dl}$. The observed range of results was 35 to $95 \mathrm{ng} / \mathrm{l}$; all values fell well below the $99.7 \%$ confidence limits for the normal range, and the geometric mean was as low as $66 \mathrm{ng} / \mathrm{l}$ (Fig. 1).

\section{COMPARISON OF E. COLI AND E. GRACILIS ASSAYS}

One hundred and twenty-two sera, the cobalamin concentrations of which were determined with the $E$. coli assay, were also measured using $E$. gracilis. A comparison of the results obtained by both methods is summarised in Figures 1 and 2. The correlation between both assays $(\mathrm{r}=0.97, \mathrm{P}<0.001)$ was excellent and the calculated regression line shown in Fig. 3 was not significantly different from the $\left(45^{\circ}\right)$ line of identity.

Normal subjects

In normals, the $E$. coli assay gave lower results with 


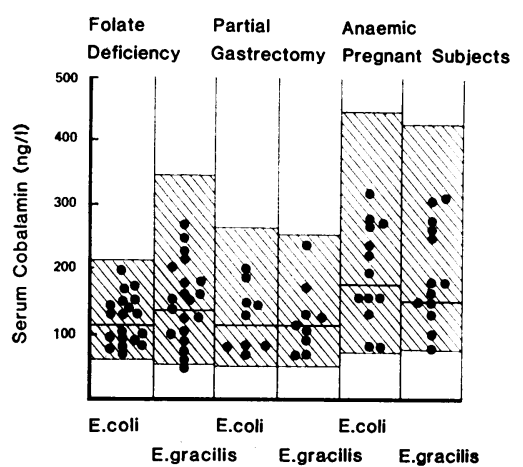

Fig. 2 Serum cobalamin concentrations in patients with megaloblastic anaemia due to folate deficiency and in gastrectomy and anaemic pregnant subjects. Solid line represents geometric mean and the shaded area represents the calculated range (mean $\pm 2 S D$ ).

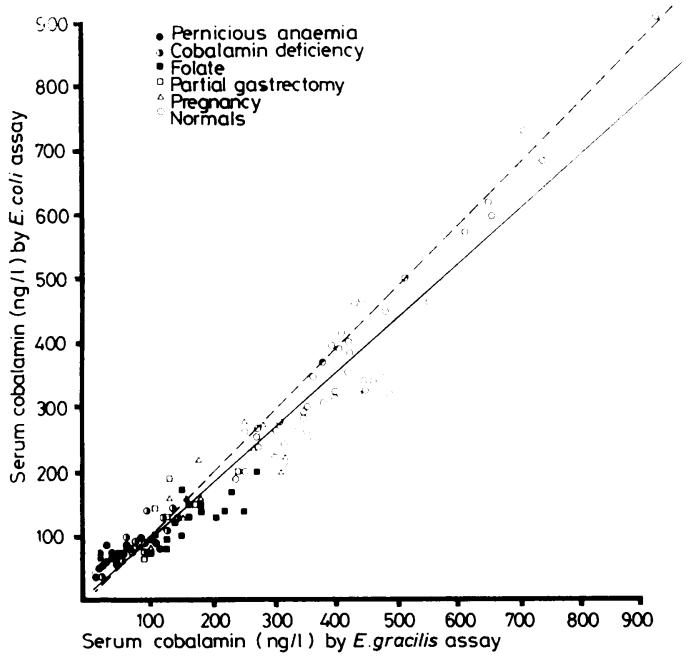

Fig. 3 Correlation between results of $\mathrm{E}$. coli and E. gracilis assays of serum cobalamin concentrations in normals and in patients investigated. Regression line (solid line): $y=0 \cdot 88 x+10 \cdot 3$. Ideal correlation (line of identity) is represented by the broken line.

a calculated range of 175 to $710 \mathrm{ng} / \mathrm{l}$ and a mean of $350 \mathrm{ng} / \mathrm{l}$ compared with a range of 225 to $730 \mathrm{ng} / \mathrm{l}$ and a mean of $405 \mathrm{ng} / \mathrm{l}$ with the E. gracilis method (Fig. 1). The correlation $(r=0.95, \mathrm{P}<0.001)$ between the results was very good and the regression line $(y=x-63)$ was almost parallel to the line of identity (slope $=1.04 \pm 0.05 \mathrm{SE}$ compared to one). However, the intercept was $-62.6 \pm 23.75 \mathrm{SE} \mathrm{ng} / \mathrm{l}$; in other words, in these normal subjects the $E$. coli assay results were on average $63 \mathrm{ng} / \mathrm{l}$ lower than those of the E. gracilis assay.
Pernicious anaemia and other megaloblastic anaemia due to cobalamin deficiency

Eighteen of the 20 patients with PA had a higher serum cobalamin concentration with the $E$. coli assay than with the $E$. gracilis. Thus their respective calculated ranges and geometric means were 40 to $105 \mathrm{ng} / \mathrm{l}$ and $65 \mathrm{ng} / \mathrm{l}$, and 15 to $95 \mathrm{ng} / \mathrm{l}$ and $35 \mathrm{ng} / \mathrm{l}$ (Fig. 1). In the 13 patients with cobalamin deficiency not due to PA or gastrectomy (Table 2), the serum cobalamin concentrations with both assays were higher than in patients with PA but were significantly lower $(\mathrm{P} \ll 0.001)$ than the concentrations found in normals. On average these patients were less anaemic than PA patients with a mean haemoglobin level of $12.3 \mathrm{~g} / \mathrm{dl}$ compared to $8.5 \mathrm{~g} / \mathrm{dl}$. In the cobalamin-deficient group the results with $E$. coli and $E$. gracilis were similar, their respective ranges being 40 to $200 \mathrm{ng} / \mathrm{l}$ and 30 to $230 \mathrm{ng} / \mathrm{l}$ and their means 90 and $80 \mathrm{ng} / \mathrm{l}$, respectively (Fig. 1).

Considering all patients with cobalamin deficiency, including patients with PA, the correlation between $E$. coli and $E$. gracilis assay results was highly significant $(\mathrm{r}=0.94, \mathrm{P}<0.001)$.

\section{Total and partial gastrectomy}

Eight patients had had a partial gastrectomy and one patient had had a subtotal gastrectomy. Six of these patients had subnormal serum and red cell folate concentrations. In these patients the cobalamin levels measured by $E$. coli and $E$. gracilis were significantly lower than in normals $(\mathrm{P}<0.002$ and $\mathbf{P}<\mathbf{0 . 0 0 1}$, respectively) and similar to the concentrations found in patients with mild cobalamin deficiency (with normal folate levels) referred to above. The results with $E$. coli ranged from 50 to 265 $\mathrm{ng} / \mathrm{l}$ with a mean of $115 \mathrm{ng} / \mathrm{l}$. These results were almost identical with the $E$. gracilis results which ranged from 50 to $255 \mathrm{ng} / 1$ with a mean of $115 \mathrm{ng} / \mathrm{l}$ (Fig. 2).

\section{Megaloblastic anaemia due to folate deficiency}

In 20 patients megaloblastic anaemia was considered to be due to folate deficiency. The haemoglobin concentration in these patients ranged from 5.0 to $14.3 \mathrm{~g} / \mathrm{dl}$ with a mean of $10.7 \mathrm{~g} / \mathrm{dl}$. Their serum and red cell folate concentrations were low, they absorbed $\mathrm{B}_{12}$ normally, and responded to physiological doses of folic acid. However, the serum cobalamin concentration with $E$. gracilis ranged from 50 to $270 \mathrm{ng} / \mathrm{l}$, and although the serum cobalamin levels increased in some patients after treatment with folate some appeared to suffer from deficiency of both cobalamin and folate. The results with the $E$. coli assay were significantly lower than normal $(\mathrm{P}<0.001)$ but were significantly higher than the results found in PA $(\mathrm{P}<0.001)$. The correlation 
between the $E$. coli and $E$. gracilis results $(\mathrm{r}=0.84)$ was highly significant $(P<0.001)$, the range and geometric mean with $E$. coli being 60 to $215 \mathrm{ng} / 1$ and $115 \mathrm{ng} / \mathrm{l}$ compared to 55 to $350 \mathrm{ng} / \mathrm{l}$ and $135 \mathrm{ng} / \mathrm{l}$ with the $E$. gracilis assay.

\section{Anaemic pregnant women}

Fifteen randomly selected pregnant women with a haemoglobin concentration of $10 \mathrm{~g} / \mathrm{dl}$ or less were studied. Two of these 15 women had megaloblastic anaemia of pregnancy due to folate deficiency and their results are given with the folate deficient group. Six of the 13 patients had subnormal serum cobalamin concentrations with the $E$. coli assay. The calculated range was 75 to $450 \mathrm{ng} / \mathrm{l}$ with a mean of $180 \mathrm{ng} / \mathrm{l}$, which is lower than the normal mean. There was excellent agreement between the results of the two methods (Fig. 2).

\section{Discussion}

In this improved $E$. coli assay maximal extraction of cobalamin from serum was achieved at $\mathrm{pH} 4 \cdot 9-5 \cdot 0$ using $0.02 \mathrm{M}$ acetate buffer (Fig. 4) to which 0.11 $\mathrm{mmol} / \mathrm{l}(5.5 \mathrm{mg} / \mathrm{l})$ sodium cyanide was added. From this extraction process a clear supernatant and complete recovery of added cobalamin was obtained. Previously a pH of $4.5^{8}$ had been used, and even distilled water with added cyanide was used. ${ }^{8}$ The latter technique, in particular, was unsatisfactory

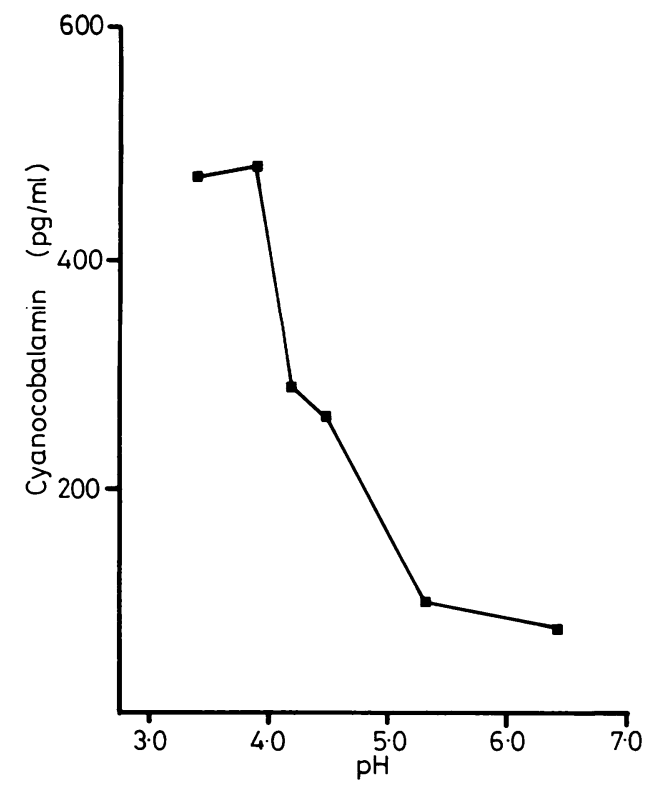

Fig. 4 The pH optimum for the extraction of serum cobalamin as measured by $\mathrm{E}$. coli assay. since a clear deproteinised serum could not be obtained.

The optimal growth and response of $E$. coli was obtained by the addition of nicotinic acid, paraaminobenzoic acid, and sodium acetate to the basic medium of Burkholder ${ }^{9}$ and the removal of sodium citrate. Biotin and aspartic acid were also found to increase the growth of $E$. coli, after the start of this study, and were not included in the assay medium for the uniformity of this work.

By analysing the different growth phases of the $E$. coli cultures, grown under optimal conditions, it was possible to ensure that an actively growing inoculum was used. In the previously used methods, the inoculum was prepared directly from the stock culture, ${ }^{810}$ which does not give a fast growing inoculum.

With the $E$. coli assay there was excellent discrimination between normal subjects and patients with PA or with cobalamin deficiency due to other causes; their diagnoses are shown in Table 2. The lower range and mean found in PA compared with the other cobalamin deficiencies were probably due to the severity of the deficiency. The $E$. coli assay results correlated very well with the $E$. gracilis results $(\mathrm{r}=0.97, \mathrm{P}<0.001)$ and had the same diagnostic significance, differing only in some minor aspects. Thus in normals the $E$. coli assay results were lower than the $E$. gracilis assay results. At the lower limit of PA (less than $100 \mathrm{ng} / \mathrm{l}$ ) higher values were obtained with the $E$. coli assay. The reason for these minor differences is uncertain.

It is clear that, under strictly controlled conditions, the results of the two microbiological assays of widely different specificities were similar. In other words, even with $E$. coli, which is a most catholic test organism in its response to cobamides, ${ }^{3}$ the results did not approximate the higher results reported with the RID assay. ${ }^{12}$ Furthermore, these microbiological assays gave similar results even in conditions where particularly high results have been found with the RID assay, such as pregnancy, ${ }^{11}$ post gastrectomy ${ }^{2} 12$ and folate deficiency. ${ }^{1314}$

In other words, the present study has failed to detect the presence of hitherto unknown cobamides in serum. However, it is conceivable that the difference between RID assay and the microbiological assays is due to a biologically inactive cobamide(s). If this is so then the results of the differential assays of $E$. coli and $E$. gracilis indicate that these cobamides are not the commonly known, naturally occurring cobamides that show $E$. coli activity nor are they the isomeric monocarboxylic acids of cobalamin in serum which show $E$. gracilis activity. The available evidence ${ }^{15}$ suggests that, apart from the known cobalamins, normal human serum also 
contains cobamides which could be separated by paper chromatography. However, it still remains necessary to substantiate and confirm these findings.

I wish to thank Professor DL Mollin for his valuable criticism, Mr JEH Shaw, Department of Physics at the College of St Bartholomew's Hospital, for excellent advice on statistics, and Mi S Soneji for performing the E. gracilis assays.

This work was supported in part by the Wellcome Trust.

\section{References}

${ }^{1}$ Wide $\mathrm{L}$, Killander A. A radiosorbent technique for the assay of serum vitamin $\mathrm{B}_{12}$. Scand J Clin Lab Invest 1971; 27:151-9.

${ }^{2}$ Green R, Newmark PA, Musso AM, Mollin DL. The use of chicken serum for measurement of serum vitamin $B_{12}$ concentration by radioisotopic dilution: Description of method and comparison with microbiological assay results. Br J Haematol 1974;27:507-26.

${ }^{3}$ Smith EL. Analogues. In: Methuen's monographs on biochemical subjects. Vitamin $\mathrm{B}_{12}$. London: Methuen; New York: John Wiley, 1965;79-90.

${ }^{4}$ Davis BD, Mingioli ES. Mutants of Escherichia coli requiring methionine or vitamin $B_{12} . J$ Bacteriol 1950; 60:17-28.

${ }^{5}$ Hutner SH, Bach MK, Ross GIM. A sugar-containing basal medium for vitamin $\mathrm{B}_{12}$ assay with Euglena: application of body fluids. J Protozool 1956;3:101-12.

${ }^{6}$ Anderson BB. Investigations into the Euglena method for the assay of the vitamin $\mathrm{B}_{12}$ in serum. $J$ Clin Pathol 1964;17:14-26.
' Scholes PM. The maintenance of microbiological assay organisms as freeze dried culture. Analyst 1961;86: 714-9.

3 Aronovitch J, Grossowicz N. Determination of vitamin $\mathrm{B}_{12}$ with an Escherichia coli mutant. Its advantage in clinical use. Am Ass Clin Chem 1958;4:22-6.

${ }^{9}$ Burkholder PR. Determination of vitamin $B_{12}$ with a mutant strain of Escherichia coli. Science 1951;114: 459-60.

10 Baker H, Frank O, Pasher I, Sobotka H. Vitamin $B_{12}$ in human blood and serum. 1. Comparison of microbiologic assays using normal subjects. Clin Chem 1960; 6:578-81.

${ }^{11}$ Lawrence C, Klipstein FA. Megaloblastic anaemia of pregnancy in New York. Ann Intern Med 1967;66: 25-34.

${ }_{12}$ Raven JL, Robson MB, Walker PL, Barkhan P. Improved method for measuring vitamin $\mathbf{B}_{12}$ in serum using intrinsic factor ${ }^{57} \mathrm{CoB}_{12}$ and coated charcoal. $J$ Clin Pathol 1969;22:205-11

${ }^{13}$ Hoff brand AV. The megaloblastic anaemias. In: Goldberg A, Brain MC, eds. Recent advances in haematology. Edinburgh: Churchill Livingstone, 1971;1.

14 Raven JL, Robson MB, Morgan JO, Hoffbrand AV. Comparison of three methods for measuring vitamin $\mathrm{B}_{12}$ in serum: radioisotopic, Euglena gracilis and Lactobacillus leichmannii. Br J Haematol 1972;22: 21-31.

${ }^{15}$ Kolhouse JF, Kondo H, Allen NC, Podell E, Allen RH. Cobalamin analogues are present in human plasma and can mask cobalamin deficiency because current radioisotope dilution assays are not specific for true cobalamin. N Engl J Med 1978;299:785-92.

Requests for reprints to: Dr NA Sourial, Department of Haematology, St Bartholomew's Hospital, West Smithfield, London EC1A 7BE. 